\title{
Orfa Kelita Vanegas Vásquez, Imaginarios políticos del miedo en la narrativa colombiana reciente. Ibagué, Editorial Universidad del Tolima, 2020
}

\author{
Carolina Sancholuz
}

Cita sugerida: Sancholuz, C. (2021). [Revisión del libro Imaginarios políticos del miedo en la narrativa colombiana reciente por O. K. Vanegas Vásquez] . Orbis Tertius, 26(34), e224. https://doi.org/10.24215/18517811e224

La narrativa colombiana de los años cincuenta del siglo XX hasta nuestro presente, centrada en episodios complejos como El Bogotazo y la violencia política y social, el narcotráfico y los enfrentamientos entre diversos grupos armados, se ejemplifica en una buena parte de la obra de Gabriel García Márquez, Germán Espinosa, Gustavo Álvarez Gardeazábal, Laura Restrepo, Héctor Abad Faciolince, Arturo Alape, Fernando Vallejo entre otros autores y autoras. Se reconoce este período como el de la Violencia, cuya mayúscula resalta la condición constante y dramática de su huella explícita, que atraviesa los modos de representación ficcional del horror. En Imaginarios políticos delmiedo en la narrativa colombiana reciente Orfa Kelita Vanegas Vásquez regresa a la violencia del narcoterrorismo, la criminalidad, la corrupción política, presentes en un repertorio novelístico publicado en las primeras décadas del siglo XXI. Pero lo hace desde un enfoque novedoso que implica un productivo desvío respecto de cierta cristalización en los modos de leer esta literatura bajo perspectivas predominantemente socio-históricas. Sin dejar de lado los aportes del entramado crítico previo, la autora elige fijar su atención en el miedo como emoción que afecta a las víctimas. Este giro subjetivo y afectivo favorece percibir en la escritura los efectos de la violencia, en cuanto el conjunto de novelas abordado se interesa especialmente en registrar y nombrar la sensibilidad herida, darle espacio a lo emocional traumático del ciudadano común. Delirio (2004) y Hot Sur (2012) de Laura Restrepo; El olvido que seremos 
(2006), de Héctor Abad Faciolince; Los ejércitos (2007), de Evelio Rosero; El ruido de las cosas al caer (2011), de Juan Gabriel Vásquez; Plegarias nocturnas (2012), de Santiago Gamboa y Los derrotados (2012), de Pablo Montoya, conforman el corpus central analizado que, asimismo, entabla importantes diálogos con otras obras y escritores colombianos y latinoamericanos. La incorporación del concepto de "miedo político" vinculado a la estética literaria y su articulación con la categoría de sujeto desde la particularidad emocional de la víctima, proyecta nuevos horizontes de sentido para responder a una de las preguntas clave que recorren este estudio: “¿Cuáles son los procedimientos de escritura que visibilizan, procesan y constituyen el 'miedo político' como estética alternativa a los modos como habitualmente la narrativa colombiana ha simbolizado la violencia del país?" (p. 13). Vanegas Vásquez subraya cómo en la narrativa reciente de su país se ha desplazado el foco de interés hacia las respuestas del sujeto-víctima, cuya sensibilidad afectiva desborda el plano personal para abarcar lo colectivo y comunitario, destacando asimismo las innovaciones poéticas del lenguaje que despliega cada escritor y escritora al momento de nombrar, relatar, imaginar e incorporar las diversas formas de la violencia y de la realidad histórico-social-política en sus obras.

Uno de los aciertos del libro radica en un relevamiento exhaustivo desde el punto de vista teóricoconceptual respecto del miedo entendido como emoción política y del impacto del imaginario emocional en torno a la violencia, a partir de diversas perspectivas, provenientes de los estudios culturales, la filosofía política, la historia de las emociones, la sociología, la psicología cognitiva, entre otros, que han enfocado lo afectivo como objeto de análisis. Asimismo se destaca la insoslayable referencia a los contextos específicos de la violencia en Colombia. Pero lo interesante es que, tanto el aparato teórico que sustenta la lectura crítica del corpus como el marco histórico-político, se articulan en un entramado constante con las obras seleccionadas. Esto es, no se ingresa a las obras a partir del andamiaje teórico y contextual sino que estos se construyen y reconstruyen a través de la indagación del miedo que se concreta en imágenes, tropos, recursos retóricos, metáforas y distintos procedimientos de cada novela abordada. Entre ellos sobresale el profundo y cuidadoso acercamiento que realiza Vanegas Vásquez cuando se detiene en la imagen de la cabeza de la Medusa, como una tremenda alegoría del poder abusivo y de los estragos de la violencia. La aniquilación se representa a través de las escenas pavorosas que se encarnan en las acciones de decapitar, mutilar, eviscerar. No sólo se reconstruye el recorrido simbólico asociado a la Medusa en la mitología, en el arte, en varias referencias a obras canónicas de la literatura occidental sino que la autora se concentra especialmente en el campo literario latinoamericano y en el colombiano específico, para ahondar en las dimensiones simbólicas pero también concretas y materiales que tal imagen entraña. Para Vanegas Vásquez la pregnancia de esta imagen es tan brutal porque denota una praxis extrema de deshumanización y abyección. En el contexto del corpus narrativo abordado la decapitación incorpora el dilema entre lo ético y lo estético, al plantear el problema de los límites mismos de la representación de los discursos literarios y artísticos. La dinámica simbólica de la decapitación se analiza con rigor y sensibilidad a través de su incidencia en las novelas Los ejércitos de Evelio Rosero y Los derrotados de Pablo Montoya en las que "la imagen visual y literaria de los decapitados que presenta la narrativa colombiana, se vuelve una afrenta poderosa contra el olvido y registro punitivo contra quienes se han arrogado el derecho de eviscerar al otro sin miramientos." (p. 161). La incidencia de esta imagen se anuda con el estudio relevante de las fuentes fotográficas y documentales que los autores del repertorio trabajado incluyen en sus ficciones, en especial el uso de fotos bélicas. Los principios compositivos de las fotografías e imágenes visuales conforman un registro icnopoético que en la obras seleccionadas, como Los derrotados y Tríptico de la infamia de Montoya y El ruido de las cosas al caer de Vásquez, no se escinden de la escritura sino que la potencian. El recurso visual colabora y enfatiza la fuerza expresiva del discurso narrativo que desentraña el miedo y lo vuelve locución articulada.

Otra línea de análisis se recorta en novelas como El olvido que seremos de Abad Faciolince, donde el trabajo con procedimientos narrativos propios de la autoficción se ilumina a partir de la lectura complementaria de Traiciones de la memoria, libro de carácter expresamente autobiográfico del autor. Vanegas Vásquez observa cómo en la novela el narrador reemplaza la voz del padre ausente, asesinado, donde "la voz del escritor- 
narrador es vicaria de la memoria traumática y de otros sucesos de la existencia del progenitor" (p. 167). En este desplazamiento de la voz narrativa y en el marcado juego entre realidad y ficción, la reconstrucción de la muerte de su propio padre, veinte años después, le permite a Faciolince la recuperación del pasado personal que se vuelve, por su impronta violenta, política y contextual, memoria comunitaria. El abordaje de las obras de Laura Restrepo y Santiago Gamboa se propone a partir de un eje central que es la figuración de los personajes como escapados. Esta categoría, un hallazgo crítico de Vanegas, engloba a los personajes obligados a dejar su lugar de origen por las circunstancias políticas, sociales y personales que los acechan, en muchos casos incluso para resguardar sus vidas. Los escapados como concepto ostentan un peso propio en el contexto de la violencia colombiana que la autora del ensayo deslinda muy acertadamente, para diferenciar la categoría de otras afines pero sin la misma connotación como migrante, refugiado, desplazado, exiliado. En estos textos cobran centralidad los cuerpos de los sujetos, expulsados de sus territorios, afectados y atravesados por emociones como el miedo, el repudio, el asco, la vulnerabilidad extrema, cuerpos que apelan con su contundencia a la sensibilidad del lector. La indagación en la figura del escapado se articula con la del nómade y el caminante, dándole cabida al análisis de las topografías y los escenarios del miedo y del horror, tramados en el espacio urbano de varias de las novelas tratadas. Estas aproximaciones concluyen con una mirada muy sagaz sobre la emoción del resentimiento, otra exploración de los afectos ante las situaciones de injusticia y reclamo que embargan a varios personajes de las novelas. La memoria desencantada del héroe resentido "se establece en la escritura como metáfora del pasado y resistencia a la historia narrada por la voz oficial” (p. 222).

Imaginarios políticos del miedo en la narrativa colombiana reciente de Orfa Kelita Vanegas Vásquez aporta significativas respuestas analíticas y hermenéuticas a la pregunta sobre cómo se narra el miedo en la narrativa colombiana reciente, una pregunta que sigue interpelando con fuerza a los escritores y escritoras de Colombia hoy, si pensamos en la reciente aparición de La sombra de Orión de Pablo Montoya, publicada en el año 2021 en medio de una rebelión social histórica en el país. La dimensión de lo imaginario que proporciona la literatura abre las posibilidades de nombrar, representar e interpretar las violencias del pasado y de nuestro presente, aspecto que el libro de Vanegas Vásquez contribuye a problematizar. 